\title{
THE CRITIQUE OF TOTALITARIANISM IN SHAIKH AYAZ AND HABIB JALIB'S POETRY: A COMPARATIVE STUDY
}

\author{
Shafqat Hussain \\ IELL, University of Sindh, Jamshoro, Pakistan \\ Ameer Ali \\ IELL, University of Sindh, Jamshoro, Pakistan
}

\begin{abstract}
Shaikh Ayaz and Habib Jalib are very renowned figures of Pakistani modern literature. Following the trend, their literary works tend to highlight their contemporary issues. Totalitarianism is a very internationally recognized political dogma which deals with controlling a state with one-man power. In the modern political discourse, it is named as dictatorship. Therefore, the study is concerned with locating the critique of totalitarianism in the poets' poems. The researchers find the objective of finding the theme of totalitarianism in the comparative manner. The researchers answer the question that how the theme of totalitarianism is dealt with, by both poets comparatively. The research follows the comparative textual analysis method of research and is qualitative in design. The Researchers have examined some similarities and differences between the poets while treating the subject of Totalitarianism. The findings of the study rely on understanding Ayaz as an international totalitarian critic, and Jalib as a national critic. The study is significant to understand Pakistani political literature.
\end{abstract}

Key words: Pakistani Poetry; Political Injustice; Totalitarianism; Comparative Study

\section{Introduction}

Totalitarianism, according to Internet Encyclopedia of Philosophy, is a social and political concept originated at the time of fascist rule in 1920s and 1930s in Europe. Firstly, the concept was introduced by Italian theorists like Giovanni Gentile. It is basically a form of government which controls each and everything of state. It holds control over every individual in the state. It mostly emerged during cold war. Totalitarianism bears no criticism specifically valid criticism. It controls state, society and individual life. The term totalitarianism bears the sense of steep modern dictatorship owning perfectionistic approaches in utopian understanding of a society.

The concept of Totalitarianism also includes two major historical concepts: Nazism and Stalinism.

Additionally, in the beginning of twentieth century, the idea of totalitarianism stood as a political reality. Thinkers like Cal Schmitt in Germany and Giovanni Gentile in Italy assisted the formation of fascist ideology in the favor of dictatorship. Later many modern scholars like Hannah Arendt, Karl Freidrich and Brzezinski has explored its negative nature. In short, totalitarianism being a political and social form, bears no valid criticism, and controls the state by subjugating common people, oppressing their freedom of speech and any sort of political activity (p.80-101).
Similarly, both Pakistani poets, Shaikh Ayaz, Sindhi modern revolutionary and romantic poet, and Habib Jalib a wellknown Urdu revolutionary poet, stood against the then existing politics in Pakistan. The poets criticized the dictating political policies. They stepped against the totalitarianism by the civil and armed-politician of era. Both poets criticized the governmental policies of their contemporary political personalities like Ayub Khan, Yahiya Khan Zulilifkar Bhutto and Benazir Bhutto. Ayaz explicitly talked about the dictatorial era of Pakistani politics. The staunch slogans of freedom, revolution, criticism and rights for the individuals are followed in the poets' poetry.

Thus, the research, with a good assistance of comparative textual method of qualitative design, opens up the deep aspects of political satire but specifically the critique of totalitarianism in Shaikh Ayaz and Habib Jalib's poetry. The theory of Totalitarianism purposed in the book, Ideology and Power in Soviet Politics (1962) by Brzezinski is taken as a theoretical framework to analyze the data collected.

\section{II.Problem Statement}

Habib Jalib and Shaikh Ayaz are researched from many perspectives. They are given no touch with respect to the international political theory of totalitarianism. Thus, the current research aims at displaying the treatment of totalitarianism in their poetry. The researchers apply the Brzezinski's theory of Totalitarianism on Shaikh Ayaz and Habib Jalib's selected poetry. The research significantly and 


\section{Yinternational Research Journa}

p-ISSN 2202-2821 e-ISSN 1839-6518 (Australian ISSN Agency)

comparatively investigates how the poets have differently and similarly treated political concept of totalitarianism in their poems.

\section{Literature Review}

This research comparatively deals with the political form of Totalitarianism represented in the poetry of Shaikh Ayaz and Habib Jalib. For reviewing literature to clarify the subject more aptly, the researchers have selected review of literature across culture and genre, and related to the same subject-poets of this study. The poets for carrying this research belong to 20th century Pakistani society, but the researchers take in account the review of literature researched out on western literature as well as Pakistani literature. The review is referred from some political research articles, some literary research articles and sociological research articles. The following previous studies justify the research gap as this subject is not touched by the researchers throughout the history of literary research.

Raza \& Awan (2016) have critically conducted research on the topic, The Effects of Totalitarianism and Marxism towards Dystopian Society in George Orwell's Novels Animal Form and Ninety Eighty-four. The novels are discussed through the lenses of Totalitarianism, Marxism and Dystopia. The novels Animal Form, an allegorical novel (1945), and Nineteen Eighty-Four (1949) deal with the historical background of Russia. They critically shed satire on the dictatorial rule of Stalin in Russia, and twentieth century dictators: Mussolini, Hitler and Franco. Totalitarianism is a form of government in which dictators rule their countries and states according to their personal political desires. They are in nature tyrant and brutal. Totalitarianism includes capitalism and manipulates the lower class-habitant of the state. The researchers discus that Orwell's both novels are prevalent in dictators' strong position and control over economy, politics and society, and Orwell presents the brutal image of Totalitarianism which causes a dystopian society. (p. 21-37)

Elimelekh (2015) has critically conducted the research on the novel, The Eye with an Iron Lid (1980) written by an Egyptian writer, Sharif Hatatah (1923). The novel is written in the background of political freedom in the Arab vanity and rebellion against it. The researcher demonstrates the theme of totalitarianism in the novel. The novel criticizes the British colonialism and Egyptian totalitarian rule of the time. The researcher discusses the need of political freedom against totalitarian rule. Political freedom is a political theory which prevails in the western and eastern world. The nation is free to live, to earn, and to worship. The researcher points out the rebellious discourse of Hatatah against cruelty and dictating attitude prevailed in the novel for his people, nation and state.
Vol. 12 No. 012022 828012012022183 (C) Author(s)

The researcher concludes that this novel is a historical documentation of 1940 which describes all the dictators of the writer's regime who snatched the freedom of individual beings.

Awan, Fatima \& Tarique (2019) have conducted a critical research on Marxist perspective of Pakistani modern poet, Habib Jalib. They chose his famous poem, Ay Chand Yahan Na Nikla Ker (O Moon, Do not Rise Here) to reveal the theme of struggle for proletariat class. They discus that Jalib has used moon as metaphor to convey his poetic message. Jalib struggles for the rights of common and working people who remain silent and oppressed because of their totalitarian rule. The research reveals that Jalib has depicted the engrossed image of the politicians of his time that they are always busy in filling their bellies with the money of common people. They have forgotten their slavery for public. The politician's cruel attitude compels the public to sale their veiled body organs like kidneys etc to survive their life. The researchers conclude that Jalib has been a revolutionary voice for the rights of oppressed people. He criticizes the cruelty of totalitarian rule, money, power and status lusted by the capitalistic ruler of his era. (p. 24-30)

Borowski, has researched out a paper, Totalitarianism in Sociological Research (2017). The research displays the basic understanding of the term Totalitarianism. Andrzej Borowski describes the term as a political and social form which undermines state, society, and individual life. It was generated after World War II. Initially, it owned a positive connotation, but in modern time it had a negative vision. He shares the idea that totalitarian government has limitation for power. The central premise of all totalitarian system is the supremacy of legal system and the people who represents them. The totalitarian state has control over everyday life. It interferes in social life through its constituted institutions. The research also explores the origin of totalitarianism and its links to some social and economic philosophies. Borowski also refers to the emission of totalitarianism, in Russia in the time of Stalin, and in Poland in 1949 and its involvement in Polish army and police. The study comes to an end discussing that Totalitarianism, being a political and social form, bears no valid criticism, and controls the state by subjugating common people, oppressing their freedom of speech and act and any sort of political activity. (p. 80-101)

Lashari (2008) has conducted research on A Marxist Approach to Shaikh Ayaz's Selected Poetry. Moreover, the researcher interprets the theory of Marxism through the social, political, literary and economic perspective. The research comprises of the outlook of the theory and its use in the work of literature. The researcher also aims to study the theme of 


\section{Yinternational Research Journal}

p-ISSN 2202-2821 e-ISSN 1839-6518 (Australian ISSN Agency)

protesting and conveying ideological perspective through the lens of Marxism in the poetry of Ayaz. His poems reflect his staunch belief in the Marxist ideology. The research concludes that Shaikh Ayaz appears to be immersed in the Marxist approach in literature. Furthermore, he proclaims himself as the revolutionary poet of the age through his poetry. He suggests to challenge the status-quo and believes in bringing a revolution worldwide. Being a Marxist, he praises the rebellious characters and seeks for salvation in this ideology till the last drop oh his blood.

Sosa (2018) conducted research on The Demon in democracy: Totalitarianism Temptations in Free Societies. The researcher has found that the land of Poland has always given birth to political theorists who optimistically criticize liberal democracy. The researcher has written about Professor Ryszard Legutko's book, The Similarities between Communism and Liberal Democracy. The author, Ryszard Legutko, writes in his book that his native Poland and the European Union, because of their liberal-democratic character, has slowly come to show some important components regarding communist understanding of religion, politics, utopia, history, and ideology. Legutko's comparison of communism and liberal democracy is not on the basis of public policy or some others things happens in his daily life. He compared the theoretical understanding of fundamental politics and social principles, i.e. how the psyche of mankind, modernity, technology and tradition are comparatively understood in both the tenures. In answer to the question of "sameness," one can say that Ryszard Legutko expresses the main components and elements of metaphysical sameness between liberal-democracy and communism. (p. 50-52)

Stroiniska (2002) discusses about Language and Totalitarian Regimes. He describes what totalitarianism is and how Nazism and communism are different to each other but have enough similarities to see totalitarianism as a universal occurrence and its viewpoint to language. He adds that Hitler and Goebbels maintained that the more monstrous the lie the more it will be easy for the public to believe it. To support this he gives Hayek observation which said the most effective way of making everyone serve the single system of ends towards which the social plan is directed to make everyone believe in those ends. The researcher writes about Totalitarian Regimes which created a new man which means the political evolution granted the biggest chances of survival to ones who follows the new rules of the ideology, for this he gives reference of Milosz who writes that the "new man" is not just an assumption. He is the starting point to become reality. Totalitarianism promoted persuasion with changing people's thought of reality and this total effect cannot be gained without making all means of information under one single
Vol. 12 No. 012022

828012012022183 (C) Author(s)

control. In totalitarian system, the bond between reality and pseudo-reality was made through language and was unreasonable. (p. 23-29)

Losurdo (2004) discuses that Hannah Arendt's, The Origins of Totalitarianism was published in 1951, but the term, even debated for decades yet lacks a proper definition. Horkheimer and Adorno have proposed that capitalism is reason behind Nazism and violence caused by western colonizers on people. Arendt in her book has reffered totalitarian methods in Israel as terrorism and violence against Arab population.. Arendt's book has two different layers separated by the outbreak of the Cold War. Many people in France view it as anti-Semitism or imperialism. She later called it as racial imperialism. In her book through the theory of totalitarianism she explained the horrors of the 20th century. Modern day theory of totalitarianism has a deductive approach which reveals itself as arbitrary and inconclusive. Nowadays religious totalitarianism is directed towards Islam. The language of the cold war has reopened with a changed target. (p. 25-55)

Different scholars have touched totalitarianism in different perspectives and forms, but the subject poets of this study have been untouched in terms of totalitarianism by the research scholars of different eras. Thus, the researchers here intend to comparatively explore the theme of totalitarianism as a literary approach in the poems of Shaikh Ayaz and Habib Jalib.

\section{Research Methodology}

The researchers follow the following research methodology to conduct the undertaken research.

\section{A. Research Design}

Polit and Hungler (1999, 155) describe the research design as:

"A blueprint, or outline, for conducting the study in such a way that maximum control will be exercised over factors that could interfere with the validity of the research results."

This research is designed as qualitative. The selected text is comparatively analyzed in qualitative design which aims at analyzing the data deeply and insightfully to answer the research questions, solve the research problem and display the research objectives, providing logical results.

\section{B. Research Method}

The research follows the method of comparative textual analysis. The study provides the textual references from the book and poetry-website. The researchers has scanned and analyzed the collected text through comparative research method in which the researchers provide similar and contrasting elements of the subject. The researchers analyze 


\section{Yinternational Research Jourma!}

p-ISSN 2202-2821 e-ISSN 1839-6518 (Australian ISSN Agency)

the text by applying Brzezinski theory of Totalitarianism purposed in book, Ideology and Power in Soviet Politics (1962). Any piece of information in research is known as data. Researchers always need a full material of data for the analysis in the thesis/article. There are two types of data collection: primary and secondary. Here, the researchers have concerned secondary data which are taken from published (books) and unpublished sources (websites).

\section{Theoretical Framework: Totalitarianism}

The research follows the Theory of Totalitarianism in order to pursue the answers of the questions. The theory is proposed by Brzezinski in his renowned book, Ideology and Power in Soviet Politics (1962) as:

\section{“... [A] new form of government falling into the general} classification of dictatorship, a system in which

technologically advanced instrument of political power are wielded without restraint by centralized leadership of an elite movement for the purpose of affecting a total social revolution, including the conditioning of man on the basis of certain arbitrary ideological assumptions, proclaimed by the leadership in an atmosphere of coerced unanimity of the entire population." (Brzezinski, p.47)

Totalitarianism is a political and social concept in which the state controls everything. The dictators like Mussolini, Hitler and Stalin think of themselves as gods of their state. They manipulate the common people and society according to their own will. It is characterized with forced suppression. It has two basic concepts. It is a complete official and exclusive philosophy which mostly compels the common people of state to bow down before it, and it is a kind of dogma which usually forces people to do as it is ordered and not to complain even any valid compliant against it. Additionally, all the totalitarian leaders promise a good life. On contrary, they destroy the democracy by their military power. They kill, disguise, hide, and exploit millions of people socially, politically and economically.

\section{V.Textual Analysis}

The study here explores the gathered content of both, poets Shaikh Ayaz and Habib Jalib. The researchers analyze the data in the light of Theory of Totalitarianism. The researchers, in details, discuss the objective of the study and provides the interpretive answers to the research questions of the study. Also, the study analyzes the chunks form the poets individually. Later, the study follows the aim of comparing them collectively after discussing every poetic chunk from the poems. The researchers explore the chunks one by one, and provide the comparative details right after the chunks individually.
Vol. 12 No. 012022 828012012022183 (C) Author(s)

Ayaz and Jalib encompassed the elements totalitarianism in in their poetry. They raised their literary voice against such regimes in the international politics or the poets' civil regional politics of Pakistan. Their pens, with blood, shed such pains of ordinary people controlled by the totalitarian states. They remained traditional while choosing this subject because the time they lived in was of dictatorial politics in Pakistan. They faced the era of dictators in Pakistani politics, General Ayub Khan and General Zia. They seem to criticize their arm-based politics at very large. Jalib mainly criticized the regime of Ayub, Bhutto, Zia and Benazir. Some examples from their selected poems which represent the critique of totalitarianism in their poetry are comparatively explained as:

"Pinocheat! Allende's heart too is a leaf which moves Restrictions......... cannot put a stop to it with your guns and bullets!” (Ayaz, 2010).

In the aforementioned line which is taken from his very famous poems, Dictator, Ayaz poetically alludes a reference to a totalitarian ruler, Pinocheat who was the president of Latin America's country, Chile. The poet here openly demonstrates the hardships, prisons and artificial hell created by the Chilean president for the nation the indigenous people. Basically, Latin America has been dictated by the global superpower, the USA. Similarly, Ayaz poetically tries to shape the exodus political polices of Pinocheat. He portrays that the President has been dictating the ordinary people of Chile. He kills them, murders them, and rapes them, politically, economically and morally.

The above line is an allusion to the famous words of the president which he uttered that there is no leaf remaining which I cannot move in the state. Such discourse displays the brutal image of the dictator. This highlights the suffering and totalitarian power of the state as discussed in the theory of Totalitarianism. The theory also urges that during the cold war the states like Russia controlled their people with military rule under the leadership of Stalin. Ayaz here in these lines replies to the totalitarian president of Chile that there lives a leaf in Allend's heart which can move without your permission. He perhaps challenges the president that he cannot move the leaf inside Allend's heart. The leaf is free. It retains no dominance by him. He is a dictator. Now this leaf will not allow him to control it. Even, his military power cannot shake the leaf.

As Totalitarianism discusses that people under dictatorship of military rule are never free. They are always subjugated by state. Such states control even the leaf in the state. In the lines uttered by a great Sindhi poet Shaikh Ayaz leaf can be a person, and idea and a poem. For them, Ayaz wants to warn the totalitarian president that your power has no more strength. Your dictatorial polices are no more acceptable. Ayaz wants his voice to reach the Chilean people, to motivate them to 


\section{Yinternational Research Jourma!}

p-ISSN 2202-2821 e-ISSN 1839-6518 (Australian ISSN Agency)

stand against the dictator of their state. He urges them to have faith in their ideas to fight for their freedom, their free state and their democracy. Ayaz masterly displays the same real picture of Latin America's famous state Chile's picture as brutally destructed, murdered and ruled with no freedom as the Berezniki's Theory of Totalitarianism observes the totalitarian states.

Habib Jalib draws the attention of the readers and listeners directly to the capitalistic class of Pakistani society who had been ruling the state that time. Jalib directly refers the lines towards the totalitarian rulers of the state, Pakistan.

"The light which shines only in palaces, burns up the joy of the people in shadows. That kind of system, like dawn without light, I refuse to acknowledge.......... Accept". Dastoor by Jalib (Poemhunter.com).

Jalib wrote this poem in the governmental time of General Ayub khan. Following the ideology of totalitarianism which proclaims that a totalitarian state has always been a superpower for the general public, Jalib indicates towards the dictatorial and capitalistic policies of General Ayub Khan. He sheds the light on the point that the common people of Pakistan have been suffering. They are homeless. They have shelters for residence, but the ruling elites have been living palaces relaxingly. They have no care of suffering of the common people. This very idea is also highlighted in the theory of Totalitarianism that the ruling dictators always fill their bellies and have no ultimate recognition of the wounds of ordinary men. This is shaped by Jalib in his poem "Dastoor" where he claims that he does not acknowledge such capitalistic and totalitarian state where only ruling class have also luxuries. He does not admit this morning which has no good news for the ordinary people of the state.

Comparatively, both poets Shaikh Ayaz and Habib Jalib have been treating totalitarianism in a very artistic manner. They both have some similarities and some differences while dealing with the subject. The first similar thing the study has analyzed is the thematic approach which is dictating which prevails in both chunks from both poets. The other thing which is nature. Both poets utilize nature to convey their message. As Ayaz refers leaf for the hope or the common people, and Jalib mentions dawn and morning and light which bring no good news for the common people. The only and a huge which difference lies in their approaches is that Shaikh Ayaz has talked about the Chilean President who dictated the common citizen of Chile. Jalib treats the case of his own indigenous siblings' case in the era of General Ayub.

As the theory of Totalitarians proclaims that a totalitarian state has power to control each and everything in the state. So, such
Vol. 12 No. 012022

828012012022183 (C) Author(s)

states have their self-generated rules and laws. The state snatches the freedom of speech and act. This clearly is highlighted in the lines by Ayaz when he was in jail because of some writings and conferences state was not allowing that time.

\section{"The moon brightly enters my cell, ............ the fear of bombs and jet-fighters......... the moon glows........... can they put out the moon? "Black-out in the Cell Prison Cell" (Ayaz, 2010)}

The poet artistically describes the scene of cell in jail. The speaker in the poem says that moon has blown up his room with his old wounds, which seems to be result of the torture by the force in jail. This happens to be clear example of totalitarian approach of the state which was having no humanitarian approach on the poet. The speaker in the last says that he has no fear of bombing, but the rulers and dictators, and watchmen of the jail have. He symbolizes bombs as a force one day they will have to face by the ordinary people. He is talking about results of the suppression the Pakistani people were suffering, according to the poet. Ayaz symbolizes moon as a hope against totalitarian policies of the state which common people had been from. And he urges that no bomb, no gun and no dictator can forbid the hope of revolution symbolized through moon. Thus, Shaikh Ayaz also condemns the Pakistani totalitarian politics. Such targeting and controlling elements discussed by Brzezinski in the Totalitarian regimes are present here in the poetry Shaikh Ayaz.

The lines below of Jalib describe the situation and circumstances of poet's society, people and he himself. This narrates the view that the life of common people has been a turmoil in the Pakistani politics.

"This black night is not perpetual, this black night is about to pass, how long these tales of darkness will last? A new morning is about to beam". "The city Of Darkness will not Last” by Habib Jalib (Poemhunter.com).

This also narrates the theory of Totalitarianism by Brzezinski that how the totalitarian regimes control each individual's life. This political Philosophy and form causes the trouble for common people of the state. Only the capitalistic, political elites and totalitarian rulers live their life prosperously. Such idea is ironically and metaphorically is highlighted through the poetic discourse of Habib Ahmed Jalib. The poets poetically uses natural words to convey his motivational message. He calls the tyrant time a dark night, and assures that this night will pass. It is no longer going to be stagnant. This may argue that this totalitarian controlled politicos is not going to be the same. He motivates the idea that that slap of totalitarian rulers 


\section{Yinternational Research Journal}

p-ISSN 2202-2821 e-ISSN 1839-6518 (Australian ISSN Agency)

is going end. He himself wants to slap the tyrant rulers of the world and his own regime when he talks about their time as dark and purposes that this time will bright with a good morning which will bring freeze. The life of common people will be free from the tyrant rule of them. They will one day shine as the sun shines in the sky freely. The whole poem is a hope for the people against the tyrant rule in the every corner of the world.

To compare both poets, the study accomplishes the theme of totalitarianism in the most similar ways. Both poets use nature to bring the hope for the people. They both become the revolutionary hand against the totalitarian regimes. Ayaz uses moon and her light for hope and for revolution that will according to home come someday, against the totalitarian rulers of his time. Jalib also uses the words like night and morning that belong to the discourse of nature. The morning for Jalib is a new revolution. It is a transition of time. The time which will come and haunt the totalitarian regimes of the world, Pakistan and everywhere, where fascist rulers dictate the ordinary people of the world. Both poets become treatment of the wounds of the common people. Thematically, they stand stagnant. One difference can be possibly here that Ayaz is highlighting the Pakistani regime, whereas Jalib seems to become a global voice for global totalitarian regimes.

The undertaken lines apparently seem to be normal, and show the alienation of an individual. As theory of Totalitarianism urges that a military ruled-state controls the life of an individual. It oppresses them, suppress them. This happens the same in the line of Shaikh Ayaz.

\section{“Earth has no charm for me, I will fly away...... Don't oppress me......... Fly away.” (Ayaz, 2010, p.180).}

The lines apparently give the idea that the speaker has no pleasant things in life to live for because he is oppressed by someone. This line literally shows that literature in not all the time aesthetic and amusing, instead literature unveils the masks of society. Ayaz is actually and openly criticizing the regimes who control the life of an individual and oppress them brutally. The people live an undemocratic life. They become sick of their life. This voice against totalitarian regimes and governments seems a global voice. This targets no individual state but all the states having power of totalitarianism. This highlights that how a common people is snatched his life by military dictators. Ayaz poetically displays how the lust of power and wealth makes the totalitarian leaders brutal, nasty and cruel as discussed in the theory totalitarianism by Brzezinski observing the totalitarian ideas like Stalinism and Nazism.
Vol. 12 No. 012022

828012012022183 (C) Author(s)

Jalib refers to some totalitarian religious force which controls the very ordinary man of the people with politico-religious card. Jalib here following the trend of Theory of Totalitarianism criticizes the state sponsored mullahs who try to subjugate the common people on the name of Allah. Here he refers that even the state plays the religious card to subjugate the people.

"God is not yours, to him we have access.... Not look kindly on ... who oppress" "God is ours" by Jalib

(Poemhunter.com).

This happened in the dictatorship of General Zia in Pakistan. Zia was a military totalitarian ruler who originated some religious laws like blasphemy etc. He tried to capture the mind of common people with religion so that they may not get a stance against him. According to the theorist, Brzezinski, this happens in totalitarian states like Nazism who killed the thousands of Jews on the name of religion. That was a dictating policy of Hitler towards Jews. Jalib also wants to demonstrate the representation of totalitarianism in this line, and wants to provide a hope to the people that God is also ours. He sheds the hope that God knows better and He will do the justice against such religious and political totalitarian rulers who oppress them.

In the comparative analysis through the lens of theory of Totalitarianism, the study analyzes that both poets have the same thematic approach of totalitarian dictatorship. In the third analysis of the chunks, the study reveals that there are some differences between both poets while treating totalitarianism. Jalib here treats the religious totalitarianism sponsored by the state. He is of the view that state has some paid religious tycoons who oppress the people. Whereas, Ayaz treats the social totalitarianism by state. He declares that there is no freedom in life, and he wants to fly away from this life. There is only similarity which prevails in both chunks from the poets that is oppression and suppression by totalitarianism as totalitarianism's theory itself declares as a form of government which is very authoritative in nature.

Moreover, Ayaz follows the trend of totalitarianism here, and in these lines becomes very aggressive.

"White dogs, black dogs, dogs of autocracy... .... in military uniform... all alike..... fascist....how arrogant...." (Ayaz, 2010, p.168)

He calls the fascists of the world brutal and dogs. He gives the names to the fascist military rulers of the world as dogs who are white, which may highlight the international army, which may be American Army. The black refers to the eastern world's totalitarian dictators. He urges that they all are same. They all are fascist. This happens to highlight that how 


\section{Yinternational Research Journal}

p-ISSN 2202-2821 e-ISSN 1839-6518 (Australian ISSN Agency)

common people and artist have been sick of military rulers of the world. As following the theory of Totalitarianism this is displayed that Ayaz follows the internal dogma of politics handled by totalitarian and authoritarian minds. This openly claims what Totalitarianism as theoretical framework assumes. This chunks vividly signifies that Shaikh Ayaz utilizes the theory of totalitarianism in his poems in order to display the international brutality of totalitarian regimes and rulers. He criticizes such regimes in order to restore democracy which can provide a good assistance to nations to live an alluring life politically and socially.

Additionally, Jalib wrote a poem during the era of Yahiya Khan. He following the thematic approach of Totalitarianism is shading satire on the government of Yahiya khan.

"If the dacoit had not ..... Village guard as his ally.... Out foot would not be in chains.... Our victory would not defeat imply". "The government of Jack Boots" by Jalib

(Poemhunter.com)

He treats the military government as a totalitarian dictatorship. He feels no freedom of villagers. Even an army constable has a control over a civil villager. He treats the brutality of army soldiers done to the common man. Here he depicts the overall scenic image of the government of Yahiya Khan. Also, he provides an interesting idea that every victory does not mean it is right. He points out the military's fascist rule which sounds successful in the eyes of the rulers. Moreover, this same idea is discussed in the theory of totalitarianism that a totalitarian state has always a fascist rule over the individuals. Jalib follows the same idea and depicts it in his poetry nationally and globally.

\section{Findings}

While comparing both chunks in order to find the similarities and differences in the light of totalitarianism, the study concludes that Ayaz and Jalib remain very similar in this very idea. They both are aggressive and treats the military rulers very realistically according to the theory. Ayaz calls such rulers as fascist, rather international fascist like Mussolini and Hitler. Jalib is also of the same point that, they have been treating the ordinary people very brutally and they think of their victory good as Hitler considered himself good while treating the Jews brutally, theorized by Brzezinski. The only difference lies here is that Ayaz is being the voice against international fascists, and calls them dogs, and Jalib is raising his artistic hand against his own indigenous totalitarian rulers. The subject matter of both the poets is same.

In a nutshell, it is possible to argue that the poets represent totalitarianism very artfully. They both have some similarities and differences discussed above, yet they remain very honest
Vol. 12 No. 012022

828012012022183 (C) Author(s)

to their subject while treating and highlighting the wounds of common people, and ordinary cries caused by the totalitarian regimes for the commoners in Pakistan, and in the Globe. The theme of totalitarianism remains very universal for both poets.

\section{Conclusion}

The researchers come to an end that both cotemporary poets, Shaikh Ayaz and Habib Jalib have remained very sincere to their subjects. They talk about totalitarianism in a very similar and somehow different way. Further, the poets have used nature, symbols, imageries and harsh language to represent the critique of totalitarianism in their poems. The eight poems from both poets analyzed above, show that Ayaz has been a global voice for the oppression and military regime, for Pakistan as well. Jalib also is sought to be Pakistani and global poetic hand towards the brutality of totalitarian regimes which control the every individual in the state, which make the common people slave to the state. Arm-based policies are imposed. No valid criticism is beard by the political and elite tycoons of state in the world. The poets through their poems have suffered the suffering of common people. The poems seem directly addressing the common people's freedom and totalitarian regimes of the military-based politics. Moreover, this research is not final in its nature and findings. The other successive researchers on totalitarianism and the subject poets can challenge it accordingly. The researchers welcome the valid criticism with regard to this study.

\section{References}

[1]. Acheraïou, A. (2011). Questioning hybridity, Postcolonialism and globalization. Springer.

[2]. Arendt, H. (1968). Totalitarianism: Part three of the origins of totalitarianism. HMH.

[3]. Awan, A., Fatima, S., \& Tarique. (2019). "From the Haves to Have Nots": A Marxist Analysis of Habib Jalib's Poem Ay Chand Yahan Na Nikla Ker (O Moon, Do Not Rise Here). International Journal of English and Education, 8(4), 24-30. Retrieved from www.ijee.org

[4]. Ayaz, S. (2010). Songs of Freedom (1st ed.). Culture Department, Government of Sindh, 2010.

[5]. Brzezinski, Z. (1962). Ideology and power in Soviet politics. (New York: Frederick A. Praeger)

[6]. Borowski, A. (2017). Totalitarianism in Sociological Research. Retrieved on June 16, 2020. from www.worldscientificnews.com

[7]. Elimelekh, G. (2015). Rebellion in a World of Totalitarianism, Sharif Hatath's novel The Eye with an iron Lid. Journal of Arabic and Islamic Studies, 15, 179197. Retrieved from www.lancaster.ac.uk

[8]. Habib Jalib. (n.d.). Retrieved from https://www.poemhunter.com/habib-jalib/ 
[9]. Lashari, M. A. (2008). A Marxist Approach to Shaikh Ayaz's

Poetry. https://www.researchgate.net/publication/272355414_A _Marxist_Approach_to_Shaikh_Ayaz's_Poetry

[10]. Losurdo, D. (2004). Towards a critique of the Category of Totalitarianism. Historical Materialism, 12(2), 25-55. Retrieved from www.brill.nl

[11]. Polit, D. H., \& Hungler, P. B. (1999). Nursing Research: Principals and methods (6th ed.). Lippincott Williams \& Wilkins.

[12]. Poorghorban, Y. (2020). Slavery and power in Behn's Social Context; A New Historicist Reading of Oroonoko. International Journal of Language and Literary Studies, 2(4), 42-50. http://doi.org/ 10.36892/ijlls.v2i4.427

[13]. Raza, S. A., \& Awan, A. G. (2016). The Effects of Totalitarianism and Marxism towards dystopian society in George Orwell's selected fictions. Global Journal of Management and Social Sciences, 2(4), 21-37. Retrieved from www.gimsweb.com

[14]. Stroinska, M. (2002). Language and Totalitarian Regimes. Economic Affairs, 22(2). DOI:10.1111/14680270.00353

[15]. Sosa, A. (2018). The Demon in Democracy: Totalitarian Temptations in Free Societies. Perspective on Political Science, 47(1), 50-52. DOI: 10.1080/10457097.2017.1399648

[16]. Totalitarianism.(June,16,2020). https://www.iep.utm.edu/totalita/ 


\section{Manuscript Processing Footprints}

\section{A. Journal Volume/Issue Details}

This manuscript it published in Vol. 12 No. 012022 issue of IARS' International Research Journal (I'IRJ).

This is a Peer Reviewed (Refereed) International Journal published by IARS' Press Australia (International Association of Research Scholars) The Volume/Issue is a regular issue of the journal published in February 2022 Available at: https://researth.iars.info/index.php/curie.

\section{B. Copyright, License, and Publishing Rights}

- IARS' Press Australia (International Association of Research Scholars) respects the rights of the authors of research content published with IARS' International Research Journal. The "First Publication Rights" (FPR) to the original work accepted for publication at IARS' International Research Journal is granted to the Publisher of the Journal but copyright for all work published in the journal is retained by the author(s). Works published in the Journal is distributed under a Creative Commons Attribution 4.0 International License (CC BY 4.0). (This license lets others distribute, remix, adapt, and build upon your work, even commercially, as long as they credit you for the original creation. This is the most accommodating of licenses offered. Recommended for maximum dissemination and use of licensed materials.)

- After publishing the content with IARS' International Research Journal, the author holds complete right on the content for its amendments and reuse in any form. IARS' International Research Journal confirms that author(s) holds the copyright of the content.

- Author(s) grant(s) permission for their work to be indexed in part/full form in commercial and non-commercial indexes. Author(s) grant(s) permission for their work to be harvested in part/full form in commercial and non-commercial archives and distributed through them. Author(s) grant(s) permission for their work to be translated in part/full form in any language and republished and redistributed. Author(s) may enter into separate, additional contractual agreements for the non-exclusive distribution of the published version of the work, with an acknowledgement of its initial publication in this Journal.

- It is the responsibility of the author(s) to secure all necessary copyright and/or permissions for the use of third-party content in their manuscript(s). Author(s) have declared the same at the time of submission of manuscript and 'may also be required' to provide written evidence of this permission anytime in case required for any purposes.

- Publications Ethics and other Terms and Conditions as mentioned on official website of IARS' International Research Journal.

\section{Last Plagiarism Report}

SCREENED BY

$\checkmark$ iThenticate

Settings: Quotes Excluded, Bibliography Excluded

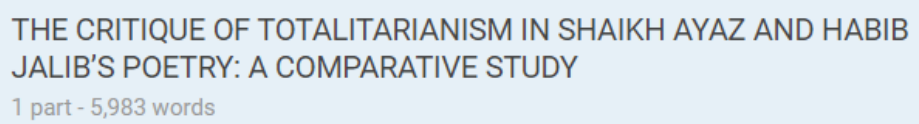

\section{Processing Track}

\begin{tabular}{|l|l|}
\hline Date of Submission & 30 January 2022 \\
\hline Date of Final Review & 27 February 2022 \\
\hline Date of Acceptance \& Schedule & 27 February 2022 \\
\hline Date of Publishing & 28 February 2022 \\
\hline
\end{tabular}

